JOANNA KWAŚNIEWSKA-POWROŹNIK* - LUBLIN

\title{
10 LAT KATALOGU KOMPUTEROWEGO W BIBLIOTECE UNIWERSYTECKIEJ KUL
}

Ostatnie lata XX wieku przebiegał w polskich bibliotekach pod znakiem zintegrowanych systemów bibliotecznych, Internetu i współpracy bibliotek w zakresie katalogowania dokumentów. Do tych prac włączyła się też Biblioteka Uniwersytecka KUL. W 2006 roku mija 10 lat prac nad komputeryzacją katalogu bibliotecznego.

$\mathrm{Na}$ początku lat 90 . XX wieku w wyniku porozumienia rektorów czterech lubelskich uczelni: Katolickiego Uniwersytetu Lubelskiego, Uniwersytetu Marii Curie-Skłodowskiej, Politechniki Lubelskiej i Akademii Rolniczej został złożony do Fundacji Mellona wniosek o dofinansowanie zakupu sprzętu i oprogramowania dla bibliotek naukowych Lublina. Pomoc otrzymano i prace nad wdrożeniem systemu komputerowego realizowano w trzech etapach. Najpierw został zakupiony niezbędny do uruchomienia programu sprzęt, następnie zakupiono oprogramowanie VTLS (Virginia Tech Library System) i w trzecim etapie przystąpiono do napełniania baz ${ }^{1}$. W BU KUL zostały uruchomione dwa moduły systemu VTLS: katalogowania wraz z obsługą kartoteki haseł wzorcowych i udostępniania. Postęp prac związanych z komputeryzacją Biblioteki był powolny. W październiku 1996 roku rozpoczęto szkolenia pracowników Oddziału Opracowania Formalnego Druków Zwartych Nowych. Entuzjastą komputeryzacji był ks. dyr. Tadeusz Stolz, który cierpliwie zachęcał do podjęcia prób tworzenia katalogu komputerowego. Zmiany kadrowe w działach opracowania i szkolenia pracowników sprawiły, że w październiku 1996 roku pierwsze opisy bibliograficzne zostały wprowadzone do katalogu komputerowego BU KUL.

* Jolanta Kwaśniewska-Powroźnik - mgr bibliotekoznawstwa, kierownik Sekcji Opracowania Alfabetycznego w Oddziale Opracowania Druków Zwartych Nowych Biblioteki Uniwersyteckiej KUL.

${ }^{1}$ G. Nowak, Koszty komputeryzacji bibliotek naukowych na przyktadzie bibliotek lubelskiego ośrodka naukowego, w: Standaryzacja kosztów w bibliotekach naukowych (Kazimierz Dolny, 2022.09.2000), Lublin 2000, s. 103. 
Dla użytkowników biblioteki do tej pory katalogi kartkowe były podstawowym źródłem informacji o zgromadzonych zbiorach. Aby zapewnić przejrzystą prezentację zbiorów i ułatwić wyszukiwanie interesującej czytelnika literatury, do 1996 roku funkcjonowały w bibliotece cztery katalogi kartkowe: alfabetyczny, systematyczny, czasopism i wydawnictw seryjnych, każda czytelnia posiadała też własne katalogi księgozbiorów podręcznych. Teraz funkcje tych wszystkich katalogów miał częściowo przejąć jeden katalog komputerowy. Było oczywiste, że latami tworzone katalogi kartkowe nie zostaną w całości przeniesione do wersji elektronicznej. Nikt nie wyobrażał sobie retrokonwersji liczącego ok. 1.630.500 jednostek bibliotecznych księgozbioru (łącznie z księgozbiorami bibliotek zakładowych), dlatego bardzo ważna była decyzja co będziemy wprowadzać do katalogu elektronicznego. Początkowo podjęto decyzję o wprowadzaniu do katalogu komputerowego z wpływów bieżących dokumentów wydanych w 1996 roku, inne otrzymywały opracowanie tradycyjne (na kartach katalogowych).

Powstający katalog komputerowy podzielił społeczność biblioteczną na dwie grupy: entuzjastów elektroniki i jej przeciwników. Dystans pomiędzy tymi grupami pogłębiały problemy techniczne, na które napotykano, zastępując maszyny do pisania i karty katalogowe komputerami. Przejście od katalogu kartkowego do komputerowego było nie tylko zmianą narzędzia pracy, ale zmianą jej organizacji i psychicznego nastawienia użytkowników biblioteki (pracowników i czytelników). Jednocześnie z modułem katalogowania zaczął funkcjonować w bibliotece moduł udostępniania. Dokonywano elektronicznej rejestracji kont czytelników i wypożyczonych książek. Pracownicy wypożyczalni wprowadzali do bazy tymczasowe opisy bibliograficzne, oklejali paskami kodowymi książki i rejestrowali w bazie egzemplarze. Duże zainteresowanie katalogiem elektronicznym spowodowało podjęcie prac nad retrokonwersją katalogów kartkowych. W pierwszych latach retrokonwersja była dotowana z różnych źródeł i wykonywana poza godzinami służbowymi pracowników. Od początku tworzenia katalogu komputerowego podjęto współpracę z CKHW (Centralna Kartoteka Haseł Wzorcowych), a wszystkie wprowadzane do katalogu dokumenty były opisywane $\mathrm{z}$ autopsji zgodnie z obowiązującymi w Polsce normami opracowania zbiorów, wpisywane w wymienny standard USMARC, a później MARC21 wykorzystywany w systemie VTLS ${ }^{3}$. Gwarantowało to spójność danych i umożliwiało kopiowanie gotowych opisów bibliograficznych z katalogów innych bibliotek wykorzystujących ten sam system biblioteczny. Przyjęte przez wszystkie biblioteki współpracujące z CKHW zasady wymagały najpierw utworzenia w CKHW hasła wzorcowego i po jego zatwierdzeniu możliwe było kopiowanie danych do własnej bazy i użycie ich w rekordzie bibliograficznym. Początki jak zwykle były ciężkie. Przyjęte zasady wydłużyły cykl opracowania o kilka dni, co spotykało się z krytyką przeciwników katalogu komputerowego i negowaniem obranej drogi. Najpierw należało w Centralnej Kartotece utworzyć potrzebne hasła wzorcowe, które następnie były

${ }^{2}$ D. Tkaczyk, Uczestnictwo bibliotek lubelskich $w$ budowaniu i wykorzystywaniu Katalogu Centralnego NUKAT, „Przegląd Biblioteczny”, 3/4 (2004) s. 237.

${ }^{3}$ A. Paluszkiewicz, Struktura danych bibliograficznych $w$ zintegrowanych systemach bibliotecznych, Warszawa 1997, s. 23. 
zatwierdzane przez zespół CKHW i po skopiowaniu do bazy KUL mogły być użyte do tworzonych opisów bibliograficznych. Od października do grudnia wprowadzono do katalogu komputerowego 1526 opisów bibliograficznych i utworzono w CKHW potrzebne hasła wzorcowe. Większość opisów bibliograficznych dla dokumentów zwartych była tworzona przez pracowników biblioteki, gdyż problemy natury technicznej (powolna sieć komputerowa, przeciążone serwery, przestarzały sprzęt) utrudniały kopiowanie rekordów z innych bibliotek. Często pracownik szybciej utworzył samodzielnie rekord bibliograficzny we własnej bazie, niż znalazł go w katalogu innej biblioteki. W pierwszym okresie ok. 80\% rekordów bibliograficznych znajdujących się w bazie było autorstwa pracowników BU KUL. W Dziale Opracowania Druków Zwartych Nowych katalogowaniem zajmowało się 8 pracowników, a do rekatalogowania poza godzinami służbowymi włączono jeszcze 12 osób z innych działów. Dla druków wydanych od 1996 roku nie drukowano kart katalogowych, czyli informacje o tych drukach dostępne były wyłącznie w katalogu komputerowym. Pociągało to za sobą konieczność organizowania szkoleń z zakresu korzystania z katalogu dla użytkowników biblioteki (bibliotekarzy i czytelników), a także zapewnienia ciągłych dyżurów bibliotekarzy służących pomocą zdezorientowanym czytelnikom.

Od 1997 roku postanowiono wszystkie wpływające do biblioteki druki zwarte opisywać w katalogu komputerowym, a także dzięki dofinansowaniom od marca podjęto próby wprowadzenia do katalogu dokumentów wydanych po roku 1994. Następnie w ramach rekatalogowania opracowano książki najczęściej wypożyczane przez czytelników i ciekawe serie znajdujące się w zbiorach BU KUL. Wszystkie opracowane formalnie dokumenty wydane po 1996 r. otrzymywały charakterystyki przedmiotowe, wydane przed tą datą zaopatrywane były w przydziały do katalogu systematycznego. Zespół katalogujący powiększył się w tym czasie do 10 osób. Rok 2001 i 2002 to wysiłki nad wprowadzeniem do katalogu elektronicznego (oprócz wpływów bieżących) ze starszych zasobów publikacji autorstwa pracowników Katolickiego Uniwersytetu Lubelskiego. Katalogowanie dokumentów w BU KUL prowadzono w dwu fazach. Najpierw sporządzano opisy bibliograficzne dokumentów w Dziale Opracowania Formalnego, a następnie książki przekazywane były do Działu Opracowania Rzeczowego i tutaj otrzymywały charakterystyki przedmiotowe $\mathrm{w}$ języku informacyjno-wyszukiwawczym KABA - dokumenty wydane od 1997 roku, a starsze książki przydziały do katalogu systematycznego. Od 1996 roku pracownicy Działu Opracowania Rzeczowego aktywnie uczestniczyli w tworzeniu kartoteki wzorcowej języka KABA.

Inaczej wyglądało opracowanie czasopism, istniejący od 1996 roku Centralny Katalog Tytułów Czasopism obligował pracowników do sporządzania opisów bibliograficznych dla tych wydawnictw zgodnie z przyjętymi zasadami, czyli online, w CKTCz posadowionym i prowadzonym w Sopocie. Do wspólnego katalogowania czasopism Biblioteka Uniwersytecka KUL przystąpiła w 1997 roku. Zmiany kadrowe i szkolenia pracowników zaowocowały dużym udziałem opisów bibliograficznych czasopism wprowadzonych do CKTCz przez bibliotekarzy KUL. Katalogujący bibliotekarze tworzyli opisy bibliograficzne w katalogu centralnym, a po skopiowaniu ich do własnej bazy podwiązywali do nich rekordy zasobu. 
W momencie przejęcia CKTCz do NUKAT autorstwa KUL było 2013 opisów bibliograficznych, co stanowiło 9,7\% całego katalogu czasopism ${ }^{4}$.

Zasadnicze zmiany przyniósł rok 2002, kiedy 5 lipca rozpoczęto współkatalogowanie w Centralnym Katalogu NUKAT (Narodowy Uniwersalny Katalog) ${ }^{5}$. W momencie startu Katalogu Centralnego w katalogu elektronicznym KUL znajdowało się 133567 rekordów bibliograficznych. 10 osób katalogowało druki zwarte i 4 osoby czasopisma. Czytelnicy przywykli już do dwutorowego przeszukiwania katalogów biblioteki, druków wydanych po 1994 roku szukano w katalogu komputerowym, a starszych w systematycznie uzupełnianych katalogach kartkowych. Wiadomość o przystąpieniu do wspólnego katalogowania u wszystkich budziła niepokój. Obawiano się wydłużenia cyklu opracowania książki i wzrostu liczby oczekujących na opisy dokumentów. Dla zobrazowania sytuacji w bibliotece posłużę się tabelą przedstawiającą liczbę wpływających do biblioteki druków zwartych i ich opracowanie.

Tabela 1. Wpływy do BU KUL i rekordy bibliograficzne wprowadzone do bazy

\begin{tabular}{|c|c|c|c|}
\hline Rok & $\begin{array}{c}\text { Liczba wol. } \\
\text { wpływających do } \\
\text { biblioteki }\end{array}$ & $\begin{array}{c}\text { Liczba } \\
\text { opracowanych } \\
\text { tytułów z wpływów } \\
\text { bieżących }\end{array}$ & $\begin{array}{c}\text { Liczba } \\
\text { opracowanych } \\
\text { tytułów w } \\
\text { rekatalogowaniu }\end{array}$ \\
\hline 1997 & 21.354 & 11.061 & 6.656 \\
\hline 1998 & 18.469 & 15.741 & 6.007 \\
\hline 1999 & 15.166 & 16.917 & 2.081 \\
\hline 2000 & 15.765 & 16.954 & 2.250 \\
\hline 2001 & 15.427 & 19.669 & 1.708 \\
\hline 2002 (do 30 VI) & 9.060 & 11.631 & 1.880 \\
\hline
\end{tabular}

W pierwszych latach funkcjonowania katalogu elektronicznego wpływy znacznie przewyższały możliwości opracowania. Na koniec 1997 roku na opracowanie oczekiwało prawie 10.300 wol. Po ponadpięcioletnim okresie pracy w systemie VTLS opracowanie druków zwartych odbywało się prawie na bieżąco. Udało się wprowadzić do katalogu większość zaległości (na opracowanie oczekiwało jeszcze ok. 3.200 wol.).

Decyzja przystąpienia do wspólnego katalogowania pociągnęła za sobą zmiany w systemie pracy w obrębie poszczególnych działów. Nowe zasady opracowania i szkolenia pracowników zachwiały płynnością opracowania. Pojawiła się groźba wydłużenia okresu oczekiwania książki na opracowanie. Planowane scalanie katalogów lokalnych ze względów technicznych i merytorycznych nie doszło do skutku. Oznaczało to, że nawet jeśli opis jakiegoś dokumentu jest w katalogu lokalnym innej biblioteki, nie można go skopiować, lecz trzeba od początku utworzyć jego opis w NUKAT. Zgodnie z przyjętymi zasadami katalogowanie odbywało się wyłącznie w bazie NUKAT z wykorzystaniem klienta Virtui. Do

\footnotetext{
${ }^{4}$ Tkaczyk, Uczestnictwo, s. 246.

${ }^{5}$ Sprawozdanie Działu Opracowania Formalnego BU KUL za rok 2002.
} 
katalogu BU KUL opisy bibliograficzne i hasła wzorcowe wchodzą w drodze kopiowania pojedynczych rekordów. Centralny Katalog prowadzony był w systemie VIRTUA, katalog BU KUL w systemie VTLS-Classic, co utrudniało szczególnie kopiowanie (kopiowanie odbywało się do pliku). Od 2003 roku nastąpiła migracja katalogu BU KUL do systemu VIRTUA, a tym samym uzyskaliśmy zgodność wersji oprogramowania z Katalogiem Centralnym. Do pracy przy tworzeniu katalogu centralnego włączyli się po przeszkoleniu także bibliotekarze bibliotek zakładowych. W ciągu pierwszych sześciu miesięcy bibliotekarze BU KUL wprowadzili do katalogu centralnego 2936 opisów bibliograficznych druków zwartych, a skopiowali do własnego katalogu 5807 rekordów autorstwa innych bibliotek ${ }^{6}$. W następnych latach współpracy proporcje te zmieniają się na korzyść rekordów kopiowanych.

Tabela 2. Rekordy bibliograficzne utworzone lub skopiowane $z$ bazy NUKAT do BU KUL

\begin{tabular}{|l|c|c|c|c|}
\hline & 2003 & 2004 & 2005 & 2006 (do 30.IX) \\
\hline Rekordy wprowadzone & 6521 & 7990 & 6700 & 4455 \\
\hline Rekordy skopiowane & 19947 & 24330 & 26237 & 12956 \\
\hline
\end{tabular}

W 2003 roku rekordy utworzone przez pracowników BU KUL stanowiły ok. 25\% wszystkich wprowadzonych do bazy KUL opisów bibliograficznych druków zwartych nowych, a w 2005 roku już tylko 20,3\%. Zaoszczędzony czas i coraz większa wprawa katalogujących w korzystaniu z klienta Virtui pozwoliły na wprowadzanie do katalogu komputerowego druków starszych, wypożyczanych przez czytelników, a nieposiadających pełnych opisów bibliograficznych.

Katalog komputerowy BU KUL po dziesięciu latach liczy łącznie 228.963 rekordy bibliograficzne i 391.368 opisów egzemplarzy ${ }^{7}$. Czytelnik znajdzie w tej bazie całą literaturę zgromadzoną w bibliotece wydaną po roku 1994 i starsze dokumenty wprowadzone w ramach rekatalogowania lub włączone do zbiorów biblioteki po 1997 roku. Włączane do biblioteki dokumenty wydane przed 1995 rokiem otrzymują opracowanie dwutorowe: w katalogu komputerowym i na kartach katalogowych, zgodnie z wcześniej obowiązującymi zasadami katalogowania. Dostęp do katalogu jest ze strony WWW biblioteki poprzez bramkę Gateway i można z niego korzystać bez ograniczeń czasowych. Strona odwiedzana jest średnio 250 razy w ciągu doby. Czytelnik ma możliwość wykonywania pewnych operacji na swoim koncie $\mathrm{z}$ domu, np. prolongata terminu zwrotu książki, zamawianie potrzebnych dokumentów, sprawdzanie statusu książki. Trzeba jednak pamiętać, że ogromne bogactwo biblioteki zamknięte jest w magazynach i katalogach kartkowych. Do katalogu komputerowego wprowadzono tylko niewielka cząstkę zbiorów BU KUL. Księgozbiór biblioteki (biblioteka główna i zakładowe) na dzień 31 sierpnia 2006 roku wynosił 1.920.781 jednostek bibliotecznych ${ }^{8}$.

${ }^{6}$ NUKAT. Statystyka [dostęp 5 października 2006], www.nukat.edu.pl.

${ }^{7}$ Stan na dzień 7 listopada $2006 \mathrm{r}$.

${ }^{8}$ Sprawozdanie BU KUL za rok akademicki 2005/2006 [dostęp 20 października 2006], http:// pater.kul.lublin.pl/fakty/sprawozdania.htm. 
Biblioteka Uniwersytecka KUL usiłuje dotrzymać kroku postępującej cyfryzacji. Obecnie, oprócz katalogu elektronicznego i baz danych udostępnianych $\mathrm{z}$ komputerów $\mathrm{w}$ bibliotece, przenoszone są do postaci cyfrowej $\mathrm{w}$ formacie PDF dokumenty zniszczone przez czas lub przez nieumiejętne korzystanie z nich. Od 2005 roku w Bibliotece rozpoczęto realizację projektu „digitalizacja”. Postanowiono przenosić do formy elektronicznej wybrane zabytki piśmiennictwa polskiego z XIX i początku XX wieku i sukcesywnie udostępniać je szerokiej rzeszy internautów na stronie Biblioteki w dziale Digitalizacja. Aktualnie tą drogą udostępniane są 3 tytuły czasopism:

Tygodnik Ilustrowany, $1867-1872$,

Meister der Farbe, 1904 - 1907,

Album Sztuki Polskiej i Obcej, 1907 - 1910.

Do wersji cyfrowej zostały przeniesione też 32 wybrane pozycje książkowe ${ }^{9}$. Jedna wydana w XVIII wieku: Vollstandiges Verzeichniss der Bücher, 13 z wieku XIX:

Bajki i przypowieści Ignacego Krasickiego. Część 1 - 2,

Doświadczeniem okazany i stwierdzony sposób,

Dworacy niedoli Zygmunta Sarneckiego,

Głos z kraju do wychodźstwa polskiego,

Księga złotych myśli, zdań, przysłów narodowych i zasad życia,

Księstwo warszawskie - Finkiel Ludwik,

Piosenki na teatrze narodowym śpiewane,

Piotr Moszyński - wspomnienie pośmiertne - Dębicki Ludwik,

Polska i Kościół Unicki,

Projekt ustawy o Izbie Rolniczej w Krakowie uchwalony,

Przyczynek do jubileuszu P. Erazma Piltza,

Słów kilka napisanych w obronie ruskiej narodowości,

Wiersz na cześć i chwałę Maryi Matki Boskiej

oraz 18 publikacji XX-wiecznych:

Ciekawe pieśni,

Komunizm i nacjonalizm w świetle chrześcijańskiego światopoglądu - Mikes Jan,

Korespondencja międzyszkolna w kraju i zagranicą,

Kwestya alfabetu litewskiego w państwie rosyjskim - Baudouin de Courtenay J.,

Miłość Sobieskich - Rogalski Leon,

Mowa Piusa XI do młodzieży polskiej, 11 kwietnia 1925 roku,

$\mathrm{Na}$ co się przyda gospodarzom wiejskim autonomia Królestwa Polskiego,

Nowy cud w Katowicach,

Obrzęd pogrzebowy Stanisława Staszica,

Obywatele - odezwa Smolki,

Pieśń Chłopskiego Stronnictwa Radykalnego,

Polacy i polskość na Litwie i Rusi - Maliszewski Edward,

Potęga przykładu - Wóycicki Aleksander,

${ }^{9}$ Stan na dzień 7 listopada 2006 roku. 
Projekt nowego podziału Królestwa Polskiego,

Rządy rosyjskie w Galicyi wschodniej - Przysiecki Feliks,

Słowiańskie nazwy miejscowości w monarchii austro-wegierskiej- Mycielski Józef,

Statut Związku Kół Pracy Młodych Ziemian,

W sprawie narodowych pamiątek - Pawłowicz Edward.

Aktualnie kontynuowane są prace nad digitalizacją dalszych roczników XIXwiecznych czasopism, a także rozpoczęto przenoszenie do wersji cyfrowej nowych tytułów:

Tygodnik Ilustrowany, 1866, 1875-1892 i 1898, 1904, 1906, 1907.

Meister der Farbe, 1908 - 1911,

Tygodnik Mód i Powieści, 1879-80, 1882, 1892,

Tkanina (Album),

Wolność, 1944,

Muzeum Sztuki Europejskiej, 1874.

Digitalizacja to nie tylko jeden ze sposobów ochrony cennych dokumentów przed zniszczeniem, ale także wygodna dla czytelnika forma prezentacji bogatego księgozbioru BU KUL. 